УДК 336.7

\title{
АНАЛІЗ ЗАСТОСУВАННЯ ІНСТРУМЕНТІВ РИНКОВОГО ПРОФІЛЮ ТА МЕТОДИКИ СКАЛЬПІНГА У ВНУТРІШНЬОДЕННІЙ ТОРГІВЛІ Ф'ЮЧЕРСНИМИ КОНТРАКТАМИ
}

\author{
Зайцева I.Ю., д.е.н, професор, \\ Задніпровський О.С., магістр, \\ Архіпова Н.М., магістр (УкрДУЗТ)
}

\begin{abstract}
У статті запропоновано власну внутрішньоденну торгову стратегію засновану на припущенні постійної присутності на ринку відкритих збиткових позицій трейдерів $i$ їх ідентифікащії за допомогою інструментів профілю ринку і скальпінгу, щзо надасть змогу приймати ефективні торгові рішення. Стратегія перевірена на реальних біржових даних ф'ючерсного контракту на фондовий індекс E-mini S\&P 500 методом тестування в реальному часі
\end{abstract}

Ключові слова: ринковий профіль, скальпінг, зона вартості, відкритий інтерес, початковий баланс, книга заявок, лімітний ордер, ринковий ордер, дейтрейдер.

\section{АНАЛИЗ ПРИМЕНЕНИЯ ИНСТРУМЕНТОВ РЫНОЧНОГО ПРОФИЛЯ И МЕТОДИКИ СКАЛЬПИНГА ВО ВНУТРИДНЕВНОЙ ТОРГОВЛЕ ФЬЮЧЕРСНЫМИ КОНТРАКТАМИ}

\author{
Зайщева И.Ю., д.э.н, профессор, \\ Заднепровский О.С., магистр, \\ Архипова Н.М., магистр (УкрГУЖТ)
}

В статье предложена собственная внутридневная торговая стратегия, основанная на предположении постоянного присутствия на рынке открытых убыточных позиций трейдеров и их идентификации с помощью инструментов профиля рынка и скальпинга, что делает возможным принятие эффективных торговых решений. Стратегия проверена на реальных биржевых данных фьючерсного контракта на фондовый индекс E-mini S\&P 500 методом тестирования в реальном времени

Ключевые слова: рыночный профиль, скальпин,, зона стоимости, открытый интерес, начальный баланс, книга заявок, лимитный ордер, рыночный ордер, дейтрейдер.

\section{ANALYSIS OF THE APPLICATION OF MARKET PROFILE INSTRUMENTS AND SCALPING METHODS IN DAY TRADING IN FUTURES CONTRACTS}

\author{
Zaitseva I.Yu., Doctor of Economic Sciences, professor, \\ Zadneprovskiy O.S., master, \\ Arkhypova N.M., master (USURT)
}

The article discusses the tools of the theory of market profile used to analyze the distribution of exchange volumes, as well as the principles of practical application of the analysis of the flow of orders and scalping elements. This paper proposes its own intraday

(C) Зайцева I.Ю.,

Задніпровський О.С.,

Вісник економіки транспорту і промисловості № 68, 2019

Архіпова Н.M. 
trading strategy based on the assumption that the traders have open unprofitable positions on the market based on data from the report on changes in the open interest of the Chicago Mercantile Exchange and their identification using non-standard application of market profile and scalping tools, which makes it possible to adopt effective trading decisions. Using the tools for analyzing the volume of transactions of market auction participants - the levels of the value area, we identified the zones of possible concentration of open unprofitable positions, which in the future can be massively closed, creating a price impulse. Using scalping tools - Level I and Level II (the flow of transactions and market depth), changes in the nature of the dynamics of the flow of orders of participants in a market auction were analyzed. The strategy was tested on real stock data of a futures contract on the E-mini $S \& P 500$ stock index by real-time testing. The test results confirm the assumption that there is a constant presence of open unprofitable positions in the market, since transactions based on the search for concentration zones of these positions were made against the direction of the price trend, which moves the market to identified zones. The massive closure of unprofitable positions, later confirmed by orders of bidders, turned out to be able to unfold the current market intraday trend, which makes it possible to make effective trading decisions and in the future increase trade capital. The use of exchange volume analysis tools in trading has proven to be very effective and can complement any intraday techniques, increasing profitability and lowering risk indicators in trading. The test results showed a critical effect of commission costs on intraday trading methods, which can significantly reduce the profitability indicator up to a loss-making strategy result

Keywords: market profile, scalping, value area, open interest, initial balance, order book, limit order, market order, daytrader.

Постановка проблеми та її зв 'язок 3 науковими чи практичними завданнями. За останні десятиліття фінансові ринки зробили потужний ривок у своєму розвитку. Цьому посприяли всеосяжні процеси глобалізації, електронні технології i загальна комп'ютеризація біржових майданчиків i засобів, що застосовуються трейдерами для контролю $\mathrm{i}$ мінімізації ризиків, а також 3 метою збагачення. Популяризація трейдингу в усьому світі і полегшення доступу до фінансових ринків рітейл-трейдерів або будь-яких інших учасників, які мають вільний капітал забезпечили небувалий приплив ліквідності на ринки, чим полегшили завдання і досягнення цілей, переслідуваних крупними учасниками ринку 3 розміщення та обігу великої частини капіталу. Така взаємодія між крупними та малими капіталами утворила грунт для дослідження поведінки тих чи інших груп учасників біржової торгівлі та розробки принципів спекуляції на цій основі.
Внутрішньоденні торгові операції сьогодні $\epsilon$ домінуючими над іншими i формують більшу частину торгового обсягу самих ліквідних інструментів за торгову сесію. Внутрішньоденні трейдери розробляють i застосовують безліч різноманітних інструментів технічного аналізу для виявлення дій та намірів крупних учасників фінансового ринку для того, щоб опинитися на «правильній» стороні та діяти разом з цими учасниками, які здатні задавати напрямок цінових тенденцій.

Аналіз поведінки тих чи інших учасників ринку змушуе внутрішньоденних трейдерів вибудовувати власні стратегії з розміщення капіталу в основному із спекулятивними цілями. Безперервний пошук найкращих елементів технічного аналізу та створення різноманітних торгових стратегій, здатних мінімізувати ризики i максимізувати прибуток, буде завжди одним 3 найбільш актуальних i пріоритетних напрямків у внутрішньоденних спекуляціях для 
сьогоднішнього покоління трейдерів і всіх наступних.

\section{Аналіз} зосереджений публікацій Аналіз на дослідження. по темі

публікацій роботах послідовників - Дж Далтона [5, 6] i Дж. Гопалакрішнан [7]. Пітер Стейдлмайер - незалежний аналітик, трейдер і член Чиказької товарної біржі, який має більше ніж сорокалітній досвід за плечима. Але, перш за все, він відомий як розробник нового підходу до аналізу біржових цін та об'ємів - «Профілю ринку» (Market Profile). Саме ці роботи розкривають суть і нюанси застосування того технічного інструментарію, який в подальшому буде застосовуватися як основа для розробки внутрішньоденної торгової стратегії. Крім цих публікацій проведено аналіз робіт по темі застосування внутрішньоденного методу торгівлі - скальпінга від авторів Дж. Грейді [8], М. Беллафіоре [9], Р. Вайкоффа [10], П. Дейвіса [11], О. Герчика [12] i матеріалів від компанії SMB Capital [13], а так само матеріалів Чиказької товарної біржі [14]. Концепція скальпінга служитиме додатковим інструментом для прийняття рішень в зв'язці з інструментами ринкового профілю.

Технічний аналіз має певні слабкі місця, його концепції такі як графічний аналіз, комп'ютерний аналіз та системи що побудовані 3 них- все це обмежено границями історичних цін та даних. Ринковий профіль в першу чергу це аналіз ринку в моменті. Можна постійно аналізувати історичні дані, але Пітер Стейдлмайер пропонує вивчати поняття evolving market - ринок, що розвивається. Одним 3 завдань індикаторного та графічного аналізу $\epsilon$ передбачення майбутнього на підставі минулих даних, замість цього Профіль ринку вивчає тільки поточний стан ринкової динаміки, ідентифікуючи вірогідності продовження чи зміни напрямку або стану ринкової кон'юнктури. Саме в цьому підході і полягає новаторство техніки автора ринкового профіля.

Невирішені частини зазначеної проблеми. На жаль П. Стейдлмайер i його послідовники в своїх роботах [1 - 7] по застосуванню ринкового профілю не залишають конкретних рекомендацій по правилам створення конкретних стратегій 3 формалізованими правилами щодо прийняття торгових рішень в кожен момент часу. Концепція профілю спрямована на розпізнавання поточного ринкового стану та поведінки різних груп учасників торгів і на підставі цього складається узагальнений прогноз майбутньої поведінки ціни i загальні рекомендації щодо застосування тих чи інших внутрішньоденних торгових тактик. Тобто, дейтрейдер має в своєму розпорядженні стратегічний, але не тактичний, інструмент для аналізу ринку.

Формування цілей статті. Метою даної статті буде доповнення техніки ринкового профілю тактичними елементами, представленими інструментами скальпінга, що надасть змогу приймати ефективні торгові рішення.

Виклад основного матеріалу. Велика кількість трейдерів, які торгують на товарних ринках мають доступ до інформації за обсягами торгівлі. Обсяг на ф'ючерсному ринку представлений у вигляді певної кількості контрактів що складалися на той чи інший товар. Інструменти, що відображають цей обсяг, дозволяють аналізувати його динаміку зміни і на основі цього аналізу будувати торгові стратегії.

Обсяг можна розкласти на два види: горизонтальний - його й називають ринковим профілем. Цей вид відображає сумарну кількість проведених угод (складених контрактів) за певним рівнем ціни за певний проміжок часу. Вертикальний - цей вид відображає сумарну кількість проведених угод 
(складених контрактів) за певний проміжок часу по всім цінам.

У 1984 році П. Стейдлмайер представив свою дослідницьку роботу і новий підхід до аналізу ринкової активності у вигляді Market Profile (Ринковий профіль) [1]. Це візуальне представлення розподілу ринкового обсягу за ціновими рівнями в часі. Ринковий профіль відображає активність трейдерів на кожному ціновому piвні. П. Стейдлмайер запропонував наступну візуалізацію ринкової активності [1]: автор розбив на 30-ти хвилинні інтервали торгову сесію i привласнив кожному інтервалу букву алфавіту. I ціна, рухаючись вертикально вгору i вниз, залишає відбиток у вигляді літери на графіку, що відповідає поточному 30-ти хвилинному періоду. Для кращого розуміння на рисунку 1 представлений цей процес детально - графік 30-ти хвилинних . барів (свічок) складається в ринковий профіль.
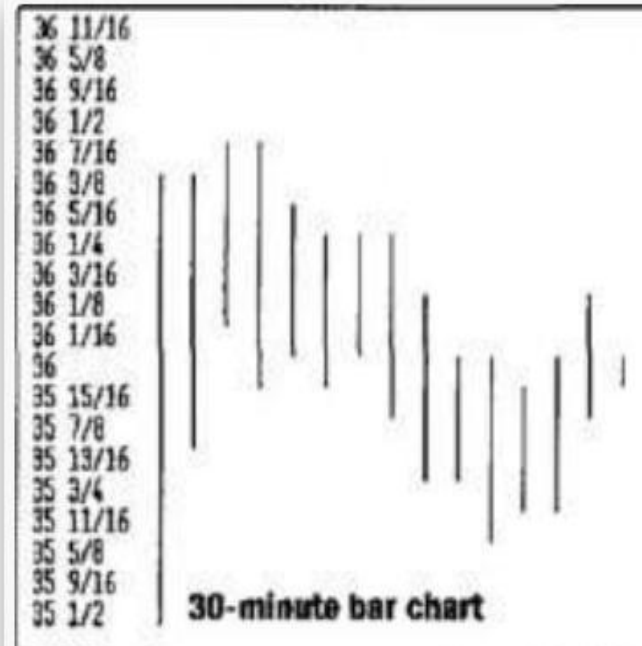

30-minute bar chart
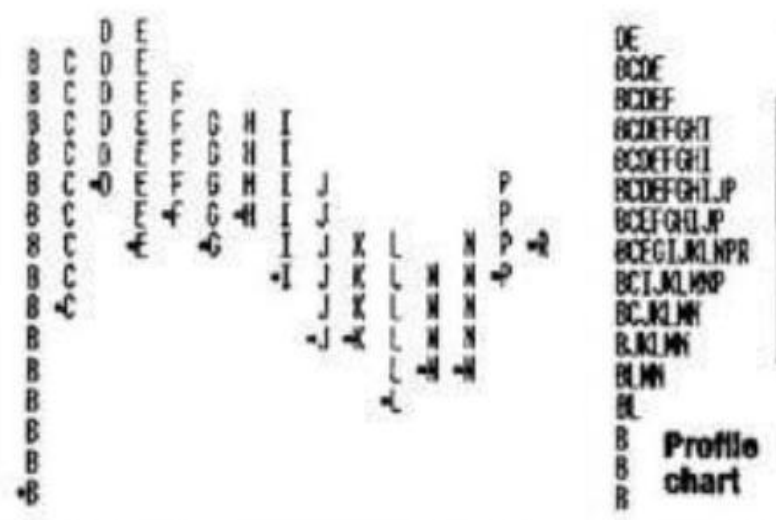

Рис. 1. Формування ринкового профілю 30-ти хвилинними інтервалами

Досліджуючи поведінку ринку крізь призму ринкового профілю, Стейдлмайер прийшов до висновку [1, 2], що ринок постійно знаходиться в пошуку справедливої ціни (процес врегулювання), яка одночасно задовольняє покупців i продавців - стан врівноваженого розподілу. В цьому випадку профіль ринку приймає форму дзвінообразної кривої - це видно на рисунку 1. У процесі пошуку ринок встановлює крайні ціни, які обмежують діапазон торгів, невиправдано низькі внизу діапазону i невиправдано високі зверху діапазону. Врівноважений ринок - це ринок, який знайшов справедливу ціну (вартість), навколо якої починається ротація - розподіл ринкового обсягу, такий рівноважний стан автор концепції позначив горизонтальним розвитком. Неврівноважений ринок - це ринок, який в даний момент знаходиться в пошуку цінової області, справедливої ціни, яка задовольнить всіх учасників. Такий ринок переміщається направлено вгору або вниз і позначений автором як вертикальний розподіл [1, 2]. Можна визначити неврівноважені короткострокові розподіли по їх формі, що нагадує краплю. В даному випадку максимальний обсяг буде розташовуватися у країв діапазону торгівлі - верхньому або нижньому (рисунок 2). 


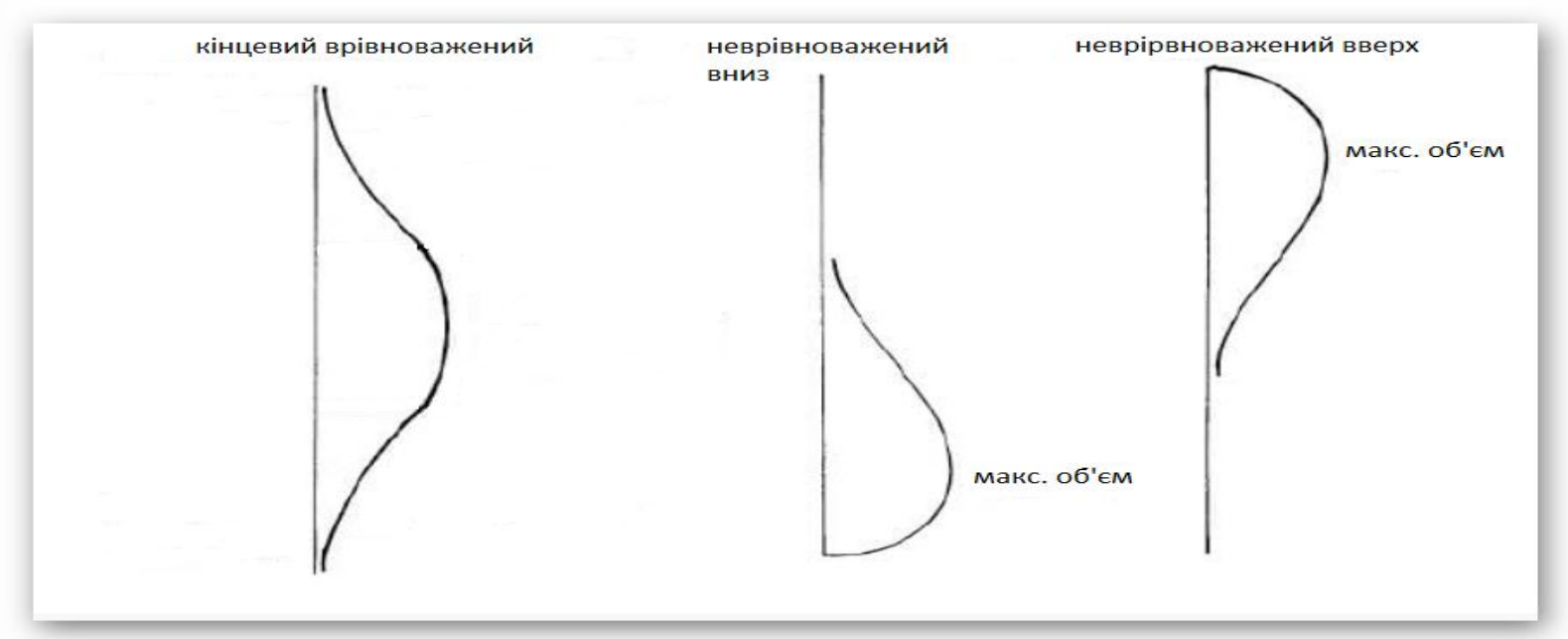

Рис.2. Горизонтальний та вертикальний розподіл (врівноважений $i$ неврівноважений стан)

У сучасному світі з появою цифрових технологій та електронної біржової торгівлі з'явилася можливість зчитування обсягу буквально кожної угоди і нанесення ïх у вигляді розподілу за часом і ціною. Ринковий профіль модифікувався в обсяговий профіль. Сучасний механізм відображення обсягового профілю для ф'ючерсного ринку показує суму контрактів, які склалися за певний часовий проміжок по кожному ціновому рівню без 30-ти хвилинного інтервального поділу i літерних позначень. Найчастіше такий профіль формується за день або торгову сесію, тим самим показуючи діапазон, в якому зосереджена найбільша кількість грошових коштів (рисунок 3 ).

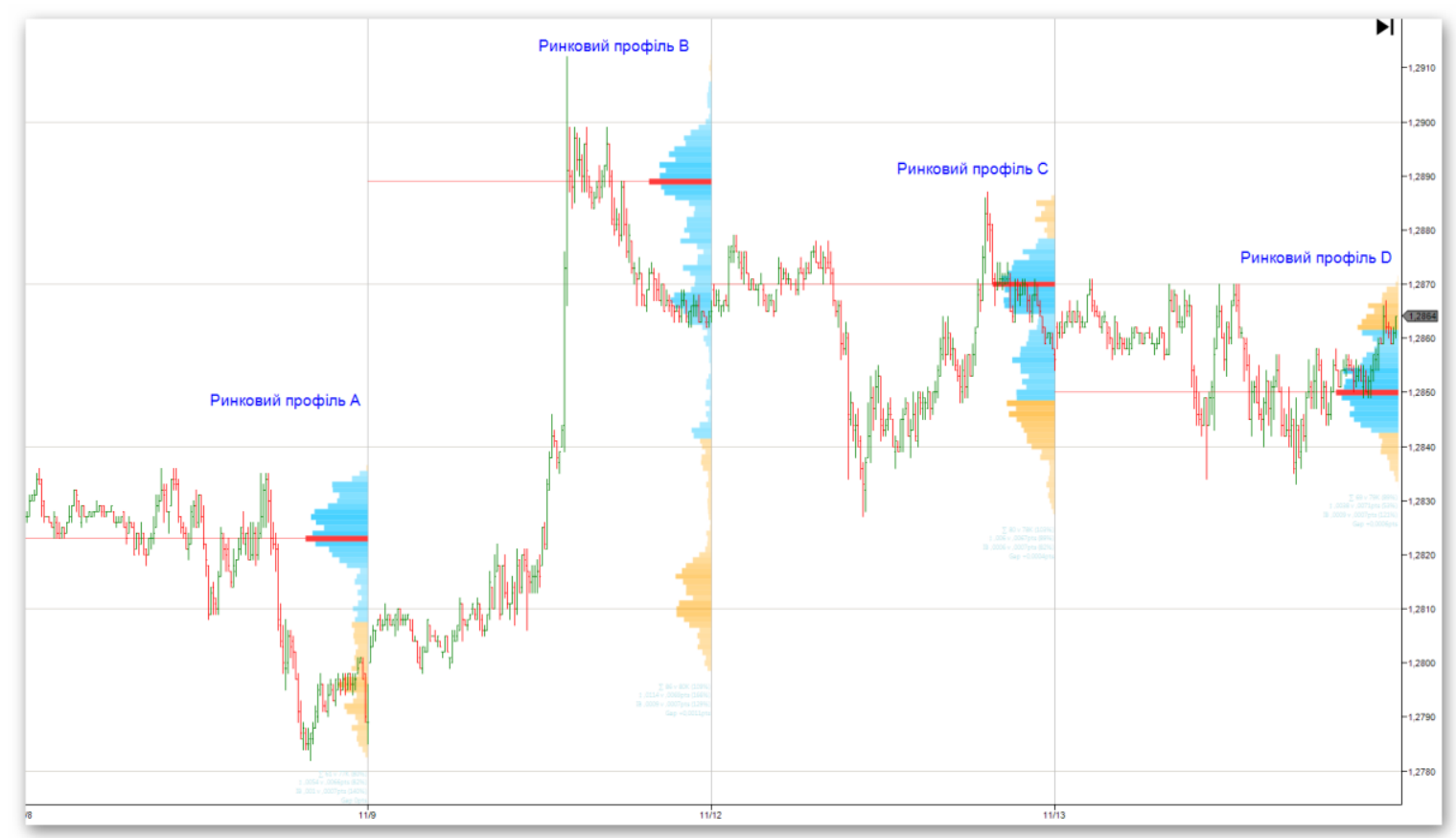

Puс. 3. Ф'ючерсний контракт 6B (GBPUSD). Горизонтальний $i$ вертикальний розподіл (врівноважений, неврівноважений стан) обсягу [складено за допомогою терміналу Ninjatrader 7] 
Ринковий профіль володіє певними елементами, на підставі і зіставленні яких проводиться аналіз поведінки ціни. Зона вартості - це діапазон цін, в якому зосереджено $68,2 \%$ всього обсягу. Значення $\quad 68,2 \%$ відповідає значенню стандартного відхилення нормального розподілу Гаусса (рисунок 4). Використовуючи значення стандартного відхилення, ми отримуємо цінові рівні
VAL - value area low, VAH - value area high, POC - point of control. POC - ціна, по якій склалася найбільша кількість обсягу. Від цієї ціни і відкладається стандартне відхилення, в результаті чого утворюються рівні VAH і VAL, рівень опору і рівень підтримки відповідно. Вони використовуються трейдерами як орієнтири для прийняття торгових рішень.

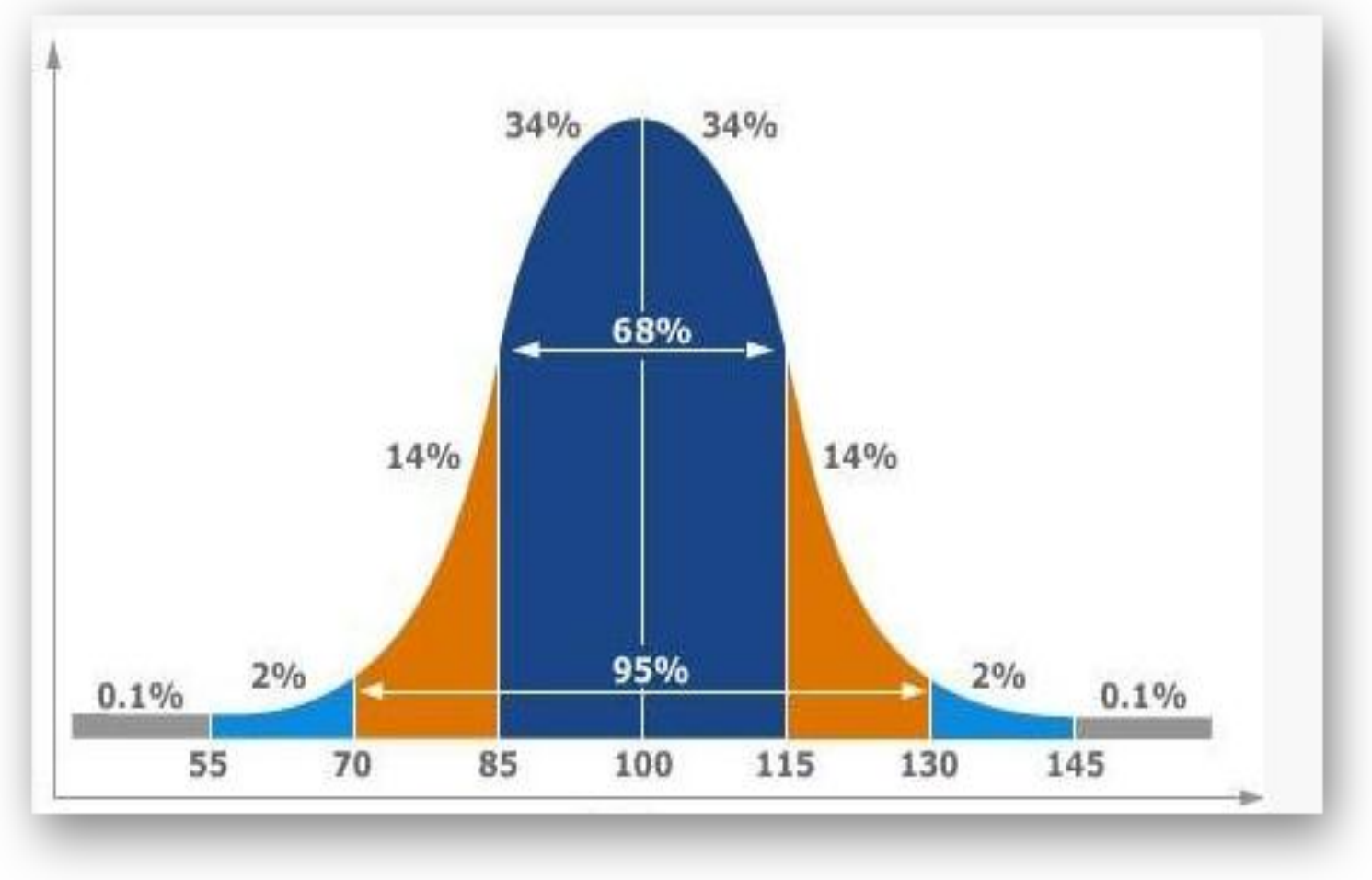

Рис. 4. Зона вартості [16]

Початковим

балансом

Стейдлмайер називає діапазон першої години торгів. На підставі глибини розширення початкового балансу ціною протягом всієї торговельної сесії П. Стейдлмайер класифікував типи торгових днів [1]: трендовий день - ринок переміщається в одному напрямку i закривається близько до екстремуму сесії, розширення діапазону - більш ніж в два рази відносно початкового балансу; нормальний день - весь діапазон або приблизно його $85 \%$ сформований в період встановлення початкового балансу, розширення діапазону практично не
П. відбувається; нейтральний день розширення діапазону відбувається в обидві сторони, розширення в одну сторону врівноважує розширення в іншу сторону; нормальний варіаційний день розширення початкового діапазону відбувається приблизно в два рази або трохи менше, закриття недалеко від максимального розширення початкового діапазону.

Якщо більш детально поглянути на цінність елементів профілю ринку для дейтрейдера, то можна виділити принципи, на яких грунтуються стратегії і взагалі прийняття торгових рішень. 
П. Стейдлмайер запропонував таке пояснення поведінки ринку $[1,2]$ : якщо ринок, перебуваючи певну кількість часу в урівноваженому стані, починає торгуватися за межами зони вартості, тобто подолав крайні зони з малим обсягом, то 3 великою ймовірністю ринок переходить в стан дисбалансу, вертикального розподілу в пошуках нової справедливої ціни. 3 цієї ситуації випливають деякі логічні правила поведінки для дейтрейдера.

Якщо відкриття торгової сесії відбувається вище попередньої зони вартості, то це $\epsilon$ ознакою сили покупців і варто шукати можливість для покупки від подоланого рівня VAH - value area high. Якщо відкриття торгової сесії відбувається всередині попередньої зони вартості, то це означає, що поточна зона вартості, точніше iii діапазон цін продовжує влаштовувати учасників торгів і слід шукати угоди на розворот всередину зони від рівнів VAH і VAL. Якщо відкриття торгової сесії відбувається нижче попередньої зони вартості, то це $\epsilon$ ознакою сили продавців i варто шукати можливість для продажу від подоланого рівня VAL - value area low. Якщо відкриття торгової сесії відбувається вище / нижче попередньої зони вартості і протягом короткого проміжку часу ринок повертається в діапазон попередньої зони вартості, тобто, учасники торгів оцінять нові ціни невиправдано високими / низькими, то з високою ймовірністю ринок подолає знову весь діапазон цієї зони. Угоди варто шукати в напрямку майбутнього проходу діапазону. Схематично ці рекомендації можна відобразити наступним чином (рисунок 5):

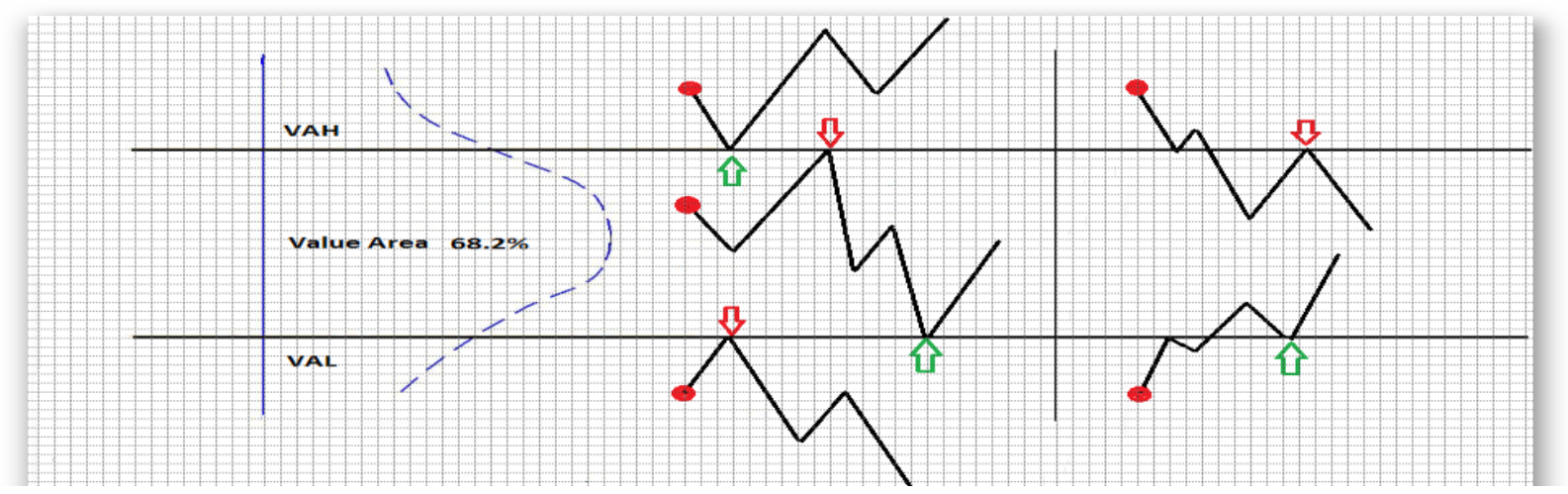

Рис. 5. Схематичні рекомендаиї П. Стейдлмайера по роботі з рівнями зони вартості [складено автором]

Скальпінг

внутрішньоденний торговий метод, в основному заснований (на товарному i фондовому ринку) на читанні потоку заявок учасників торгів. Для того щоб розібратися, що собою являє потік заявок, спершу розберемося в принципі укладення угод на біржі - зведення ордерів. Для прикладу візьмемо алгоритм зведення ордерів Чиказької товарної біржі (CME) [14].

Алгоритм FIFO працює наступним чином. Він враховує тільки дві складові ринкового аукціону - ціну та час i організований за принципом «живої черги». Ринкові ордери будуть поглинати лімітні з одного цінового рівня в порядку їх виставлення за часом на цьому рівні. Той ордер, який був виставлений першим, буде виконаний першим; той ордер, який був виставлений останнім, буде виконаний останнім. Розмір ордерів не є критерієм для виконання.

На біржі існують два типи ордерів, що приймаються від учасників - це ринковий (агресивний) і лімітний (пасивний). Лімітні ордери розміщуються учасниками в книзі заявок вище і нижче від поточної ціни, відповідно вище розміщують заявки продавці, нижче - покупці. Ринковий ордер 
на покупку (Buy Market) зводиться 3 найближчим лімітним ордером на продаж (Sell Limit). Ринковий ордер на продаж (Sell Market) зводиться 3 найближчим лімітним ордером на покупку (Buy Limit) (рисунок 6). Звернемося до прикладу, що наведено в матеріалах Чиказької товарної біржі [14]: на ринок поступив ринковий ордер на покупку в розмірі 100 контрактів за ціною 2041,25 . У книзі ордерів на ціновому рівні 2041,25 розміщено лімітних заявок сумарно на 150 контрактів. рисунку 6 лімітні ордери розміщені в порядку виставлення по часу. У цьому випадку ордер з кодом АВС стоїть першим в черзі і відповідно він буде виконаний першим. Далі черга ордера 3 кодом XYZ. Ордера ABC і XYZ будуть виконані в повному обсязі. Ордер з кодом KLM буде виконано частково в розмірі 25 контрактів, так як на цей момент залишилося всього 25 контрактів ринкового ордера. Залишок 35 контрактів лімітного ордера KLM залишиться в книзі заявок до наступної На ринкової заявки чи до його відміни.

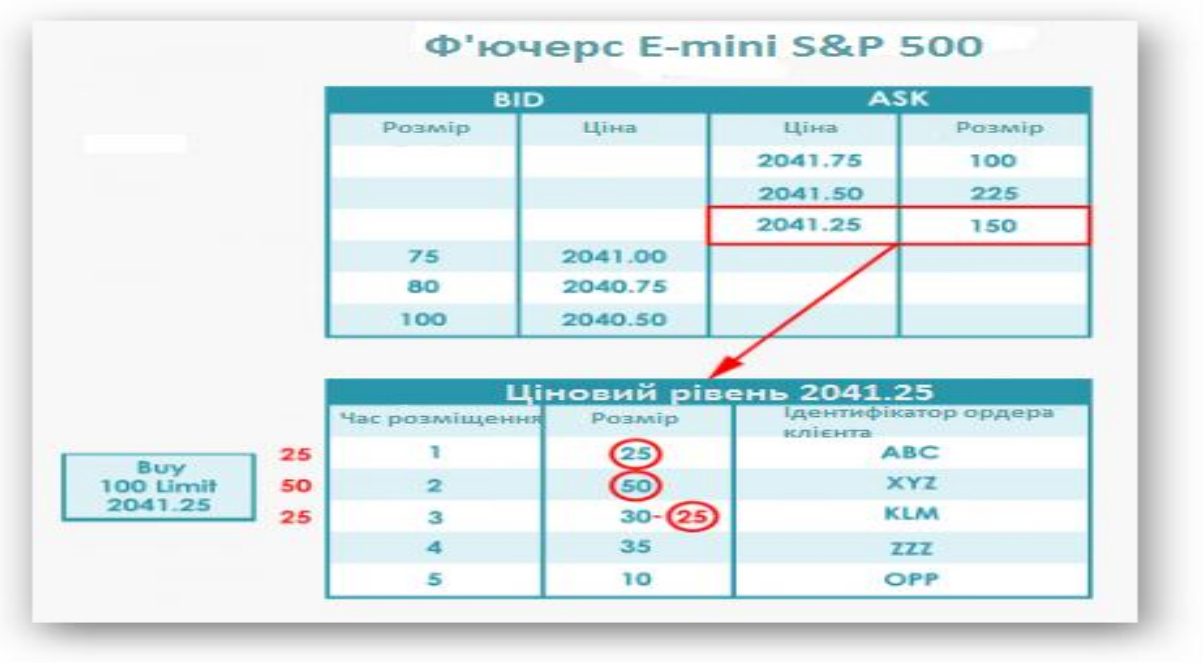

Pис. 6. Алгоритм зведення ордерів FIFO [14]

Отже, 3 алгоритму зведення ордерів випливає, що необхідною умовою для зміщення ціни в одну сторону потрібен постійний приплив на ринок агресивних, ринкових ордерів, які розбирають лімітні заявки, а також додаткове розміщення необхідної кількості лімітних ордерів 3 боку ініціативи, які здатні поглинути протилежні агресивні заявки. Тобто, для постійного зміщення ціни «вгору» ринку потрібні Buy Market ордера, підкріплені Buy Limit ордерами, які поглинають Sell Market ордера.

Тепер, маючи уявлення, за рахунок чого рухається ціна, ми можемо описати можливі умови динаміки потоку ордерів для ринкового розвороту в масштабах внутрішньоденної торгівлі. Перший варіант розвороту по потоку ордерів - розворот відбувається за рахунок вичерпування обсягу ініціативної сторони, що контролювала поточний стан і напрямок ринку. Наприклад, при зростаючому ринку контроль ціни залишається за покупцями до тих пір, поки не залишиться учасників, які бажаючих купувати за поточними цінами. Потік Buy Market ордерів закінчується або стає настільки незначним, що не здатен далі розбирати лімітні заявки від продавців. Buy Limit ордера теж припиняють виставлятися в книгу заявок i їх кількість, що залишилася не здатна стримувати навіть невеликий потік Sell Market ордерів, які і розгортають ринок. Другий варіант розвороту по потоку ордерів - розворот відбувається за рахунок поглинання всієї ініціативи, яка контролювала напрямок руху ринку. Тобто, наприклад, при зростаючій 
тенденції, ринок підходить до певної цінової області, де ціна приваблює велику кількість продавців, які здатні задовольнити абсолютно весь попит, незважаючи на його силу. 3'явилася велика кількість Sell Limit ордерів, поглинаючих yci Buy Market ордера, i після появи великого обсягу агресивних Sell Market ордерів, які розбирають все лімітні заявки від покупців, ринок починає зміщуватися в зворотному напрямку.

Подібні ринкові ситуації i відстежують дейтрейдери за допомогою інструментів Level I i Level II [11]. Level I відображає здійснені угоди в реальному часі. Трейдер може стежити за розміром обсягу угод що проходять за поточною ціною i оцінювати швидкість або інтенсивність подій. Level II показує кількість лімітних заявок на найближчих цінових рівнях від покупців i продавців. Зіставляючи показники від обох інструментів, трейдер має можливість визначати, на чиєму боці контроль над ринком. Що дає йому можливість приєднатися до домінуючої стороні. Також трейдер може ідентифікувати перехоплення ініціативи контролю над ринком, відстежуючи моделі розвороту по потоку ордерів, описані вище.

Інструменти скальпінга дозволяють трейдеру відкривати угоди за найкращими цінами, випереджаючи своїх конкурентів. Також вони дозволяють розміщувати короткі стоп-накази , що істотно знижують ризики. Скальпінг дає велику кількість можливостей для угод протягом всієї торговельної сесії і має перевагу перед іншими методами та інструментами технічного аналізу, які в основній масі не дають можливість відкривати угоди за найкращими цінами і найчастіше $є$ запізнілими.

Стратегія. Будь-яка торгова стратегія повинна базуватися на певній ідеї, припущенні - за рахунок яких властивостей ціни i ринку (технічних або фундаментальних) трейдер гіпотетично може мати прибуток. Можна запропонувати таку фундаментальну основу: 3 моменту появи i за весь час існування ф'ючерсного контракту що торгується величезна кількість учасників відкриває і закриває торгові позиції за цим контрактом, переслідуючи певні цілі. Нас цікавлять учасники-спекулянти, так як вони найбільш стурбовані ризиковою частиною своєї торгівлі - їхня мета це мінімізація збитків. Серед подібних учасників існують різні способи контролю над ризиком та управління операціями. Частина 3 них використовують стоп-накази для швидкої фіксації збиткових угод, частина 3 них використовують усереднення позицій, а частина вважає за краще «пересиджувати» збиткові угоди, тобто чекають повернення ринку до діапазону ціни відкриття їхніх угод [9]. Щоденна публікація показників стану відкритого інтересу за ф'ючерсними контрактами є доказом того, що в ринку завжди присутні відкриті збиткові позиції продавців i покупців [17]. Зростаюче позитивне значення відкритого інтересу говорить про те, що укладаються нові контракти (угоди) між вхідними в ринок покупцями і продавцями. I через певний час, ринок, зміщуючись вище або нижче цін укладення цих угод, залишає одну зі сторін у збитках. I в той момент, коли ринок повертається до цін відкриття угод, збиткова сторона закриває їх, тим самим створюючи опір руху ціни і нерідко іiі розгортає. Наша мета ідентифікувати цінові зони, де можливо зосереджені у великій кількості відкриті збиткові позиції. У цьому нам допоможе інструмент ринкового профілю. Межі ідентифікованих зон вартості виступатимуть для ринку можливими рівнями підтримки та опору, якщо в цих зонах $є$ відкриті збиткові позиції. Інструменти скальпінга будуть показувати, чи є зміни в динаміці потоку ордерів, який повідомляє про те, що трейдери схильні в поточний момент часу закривати свої збиткові позиції. 
Правила стратегії. Розділимо на дві групи тих учасників, які можуть мати відкриті

збиткові позиції . Внутрішньоденні трейдери - ті трейдери, збиткові позиції яких будуть актуальні, поки розвивається поточна торгова сесія; середньострокові трейдери ті трейдери, які мають відкриті збиткові позиції за весь період існування поточного ф'ючерсного контракту.

Угоди, засновані на закритті середньострокових збиткових позицій, будуть формуватися, якщо відкриття поточної торгової сесії відбувається за межами зони вартості попереднього або більш ранньої торгової сесії. I межі цієї зони вартості виступають орієнтирами для угод.

Угоди, засновані на закритті внутрішньоденних збиткових позицій, будуть ідентифікуватися при поверненні ринку до локальних зон вартості, сформованих поточною торговою сесією.

На рисунку 7 наведено приклад аналізу ринку і складання орієнтирів для пошуку угод.

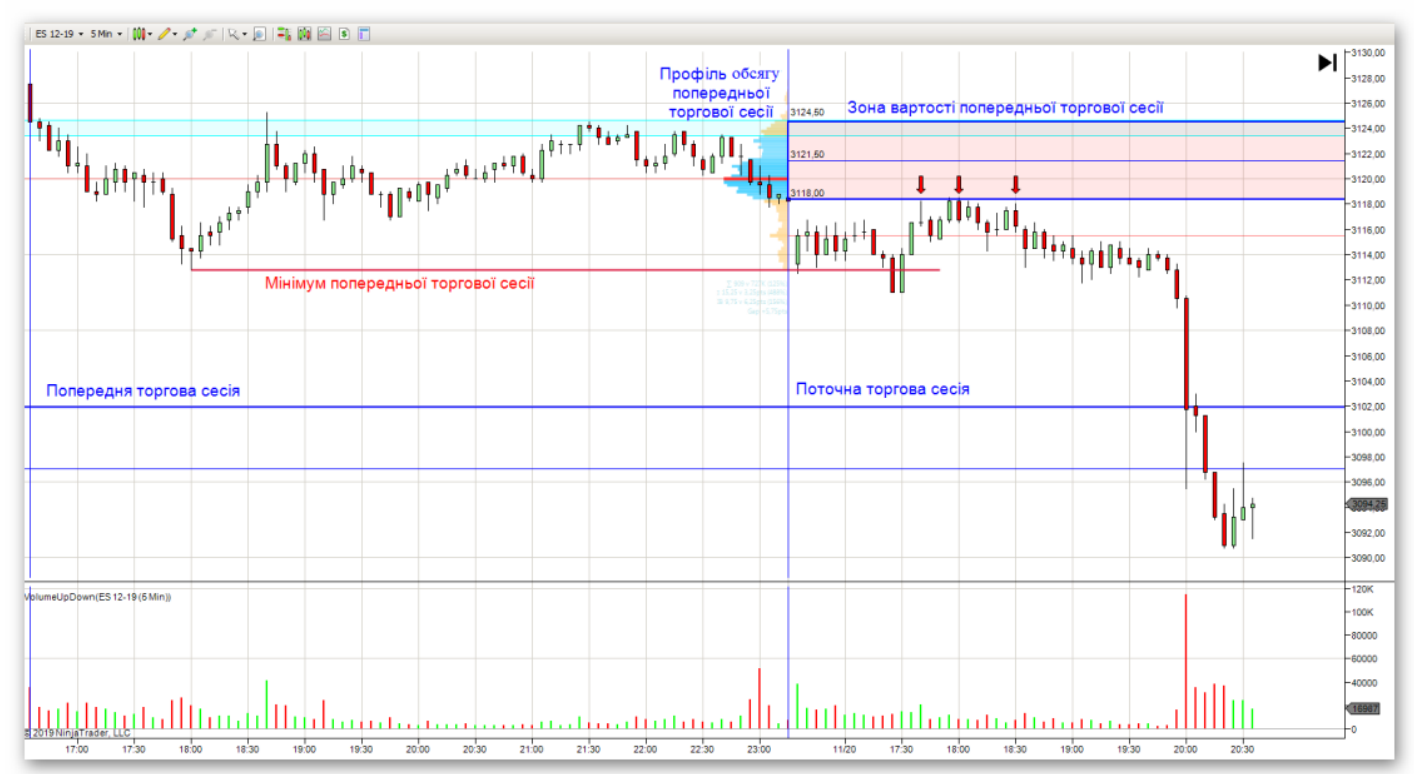

Рис. 7. Розворот від зони вартості попередньої торгової сесії [складено за допомогою терміналу Ninjatrader 7]

На рисунку 7 видно, що зона вартості попередньої сесії, показана профілем обсягу, сформована між рівнями 3124,50 i 3118,00 . Максимальна концентрація позицій знаходиться між рівнями 3121,50 і 3118,00. Наступна сесія після відкриття показує відновлення мінімуму попередньої сесії, чим можливо викликає сумнів щодо відкритих позицій у учасників, які відкрили покупки напередодні в концентрованій частині зони вартості. I при поверненні ринку до рівня 3118,00 покупці, судячи 3 усього, скористалися нагодою i стали закривати збиткові позиції. Трейдер, що відкриває продаж в цей момент разом 3 вихідними покупцями, може розраховувати на певний ціновий імпульс, що дозволяє йому зафіксувати прибуток, орієнтуючись на показання потоку ордерів або просто виставивши ордер на взяття прибутку по заздалегідь розрахованим рівнями.

Результати тестування. Тестування проводилося на ф'ючерсному контракті Е$\begin{array}{llllll}\text { mini } & \text { S\&P } & 500 & \text { (ES) } & 3 & 15.01 .2019\end{array}$ 28.11.2019. В процесі тестування стратегії використовувалися два різних методу управління ризиками. Перший передбачав відсутність стоп-наказів для угоди, але не дозволяв втрачати більше 50-ти тиків за одну сесію, тим самим моделювалася торгівля однієї з груп спекулянтів. Другий метод припускав швидку фіксацію збитків 
стоп-наказами. Фіксація прибутку проводилася або за сигналами потоку ордерів, або лімітним ордером.

Результати тестування представлені електронною таблицею [15]. У короткому викладенні: за весь період тестування скоєно 211 угод (90 покупок, 121 продаж); результат на виході без комісії: +201 тік; максимальна просадка: -103 тіка; результат на виході 3 комісією +137 тіків 3 просіданням -127 тіків.

Висновки даного дослідження i перспективи подальших робіт у цьому напрямку. Аналіз біржових обсягів здатний надати трейдеру ефективний набір рішень для отримання прибутку, будь то ринковий профіль, скальпінг або аналіз вертикального обсягу. Поєднання цих типів та інструментів аналізу можуть ефективно доповнити вже використовувані трейдером підходи в торгівлі і дозволити йому розсунути межі бачення подій, що відбуваються на ринку.

Розроблена i випробувана стратегія виявилася здатною накопичувати прибуток п плином часу, що доводить фундаментальне припущення існування відкритих збиткових позицій на ф'ючерсному ринку, а саме на ринку E-mini S\&P 500 (ES), а так же доводить те, що трейдери прагнуть закривати ці позиції, як тільки ринок надає можливість це зробити.

За результатами тестування видно, що розмір комісійних і їх сумарна кількість істотно впливає на ефективність даної торгової стратегії, як і на будь-яку іншу, розроблену під внутрішньоденний масштаб торгівлі. Пошук можливостей по зниженню розмірів комісійних видатків $\epsilon$ одним 3 найважливіших завдань для дейтрейдера.

\section{ПЕРЕЛІК ВИКОРИСТАНИХ ДЖЕРЕЛ}

1. Steidlmayer P. Markets and Market Logic [Text] / P. Steidlmayer. Porcupine Pr; 1st edition, 1986. - p. 161.

2. Steidlmayer P. Steidlmayer on Markets: Trading with Market Profile [Text] / P. Steidlmayer. Wiley Trading, 2002. - p. 224.
3. Steidlmayer P. 141 West Jackson A Journey Through Trading Discoveries [Text] / P. Steidlmayer. Steidlmayer Software; 1st edition, 1996. - p. 138

4. Steidlmayer P, Hawkins S. Steidlmayer on Markets: Trading with Market Profile (second edition) [Text] / P. Steidlmayer, S. Hawkins. John Wiley \& Sons, Inc., 2003. - p. 223.

5. Dalton J, Dalton R. Mind Over Markets: Power Trading With Market Generated Information [Text] / J. Dalton, R. Dalton. Probus Publishing Co., 1990. - p. 345.

6. Dalton J, Dalton R, Jones E. Markets in Profile. Profiting from the Auction Process [Text] / J. Dalton, R. Dalton, E. Jones. John Wiley \& Sons, Inc., 2007. - p. 224.

7. Gopalakrishnan J. Market Profile Basics Technical / J. Gopalakrishnan // Analysis of STOCKS\& COMMODITIES, 1999 [Електронний ресурс] - Режим доступу: http://traders.com/Documentation/FEEDbk_do cs/1999/12/Abstracts_new/Gopalakrishnan/Jay anthi.html

8. Grady J. No B.S. Day Trading [Електронний ресурс] / J. Grady - Режим доступу: http://www.nobsdaytrading.com /courses/basic-course/

9. Bellafiore M. One Good Trade: Inside the Highly Competitive World of Proprietary

Trading [Text] / M. Bellafiore. Wiley; 1

edition, 2010. - p.368

10. Wyckoff R. The Day Trader's Bible [Text] / R. Wyckoff. Ticker Publishing, 1919. p. 116.

11. Davies P. When to Enter [Електронний ресурс] - Режим доступу: https://www.jigsawtrading.com/learn-to-tradefutures/

12. Герчик А. Курс активного трейдера /А. Герчик. Альпина Паблишер, 2019. - 344 c.

13. Матеріали від компанії SMB Capital [Електронний ресурс] - Режим доступу: https://utmagazine.ru /posts/ 18927-shpargalka-po-chteniyu-lenty-otsmb-capital

14. Навчальні матеріали на порталі Чиказької товарної біржі [Електронний 
ресурс - Режим доступу: https://www.cmegroup.com/education/matchin g-algorithm-overview.html

15.Результати тестування внутрішньоденної торгової стратегії [Електронний ресурс] - Режим доступу: https://drive.google.com/file/d/1tUFeD4F9m4b nK4P7OzjbLAUVxHHywmqn/view?usp=shari ng

16. Офіційний сайт розробника програмного забезпечення. Orderflowtrading.ru [Електронний ресурс] Режим доступу: https://orderflowtrading.ru /torgovlya-na-birzhe/gorizontalnyy-obyom/

17. Звіт по відкритому інтересу Чиказької товарної біржі [Електронний ресурс] - Режим доступу: https://www.cmegroup.com/trading/equityindex/us-index/e-minisandp500_quotes_volume_voi.html\#tradeDate $=20191129$

\section{REFERENCES}

1. Steidlmayer P. Markets and Market Logic. Porcupine Pr; 1st edition, 1986. - p. 161.

2. Steidlmayer P. Steidlmayer on Markets: Trading with Market Profile. Wiley Trading, 2002. - p. 224.

3. Steidlmayer P. 141 West Jackson A Journey Through Trading Discoveries. Steidlmayer Software; 1st edition, 1996. - p. 138

4. Steidlmayer P, Hawkins S. Steidlmayer on Markets: Trading with Market Profile (second edition). John Wiley \& Sons, Inc., 2003. - p. 223.

5. Dalton J, Dalton R. Mind Over Markets: Power Trading With Market Generated Information. Probus Publishing Co., 1990. - p. 345.

6. Dalton J, Dalton R, Jones E. Markets in Profile. Profiting from the Auction Process. John Wiley \& Sons, Inc., 2007. - p. 224.

7. Gopalakrishnan J. Market Profile Basics Technical Guide / J. Gopalakrishnan // Analysis of STOCKS\& COMMODITIES, December, $1999 . \quad-\quad$ URL:
http://traders.com/Documentation/FEEDbk_do cs/1999/12/Abstracts_new/Gopalakrishnan/Jay anthi.html
8. Grady J. No B.S. Day Trading / J.

Grady. URL: http://www.nobsdaytrading.com/courses/basiccourse/

9. Bellafiore M. One Good Trade: Inside the Highly Competitive World of Proprietary Trading. Wiley; 1 edition, 2010. - p.368

10. Wyckoff R. The Day Trader's Bible. Ticker Publishing, 1919. - p. 116.

11. Davies P. When to Enter. - URL: https://www.jigsawtrading.com/learn-to-tradefutures/

12 Gerchik A. (2019) Kurs aktivnogo treydera [Active trader course]. Moscow: Alpina Publisher. (in Russian)

13. Materialy vid kompanii SMB Capital [Materials from SMB Capital]. - URL: https://utmagazine.ru/posts/18927-shpargalkapo-chteniyu-lenty-ot-smb-capital

14. Navchalni materialy na portali Chykazkoi tovarnoi birzhi [Study Materials on the Chicago Commodity Exchange Portal]. URL: https://www.cmegroup.com/ education/matching-algorithm-overview.html

15 . Rezultaty testuvannia vnutrishnodennoi torhovoi stratehii [Test results of the intraday trading strategy]. - URL: https://drive.google.com/file/d/1tUFeD4F9m4b nK4P7OzjbLAUVxHHywmqn/view?usp=shari ng

16. Ofitsiinyi sait rozrobnyka prohramnoho zabezpechennia Orderflowtrading.ru [Official website for software developer]. - URL: https://orderflowtrading.ru/torgovlya-na-

birzhe/gorizontalnyy-obyom/

17. Zvit po vidkrytomu interesu Chykazkoi tovarnoi birzhi [Report on the open interest of the Chicago Commodity Exchange]. - URL: https://www.cmegroup.com/trading/equityindex/us-index/e-minisandp500_quotes_volume_voi.html\#tradeDate $=20191129$ 